\title{
The Molecular Neuroimaging of Tremor
}

\author{
Jacopo Pasquini ${ }^{1,2}$ (1) $\cdot$ Roberto Ceravolo ${ }^{3,4}$ (I)
}

Accepted: 17 October 2021 / Published online: 24 November 2021

(c) The Author(s) 2021

\begin{abstract}
Purpose of Review Tremor is a hyperkinetic movement disorder most commonly encountered in essential tremor (ET) and Parkinson's disease (PD). The purpose of this review is to summarize molecular neuroimaging studies with major implications on pathophysiological and clinical features of tremor.

Recent Findings Oscillatory brain activity responsible for tremor manifestation is thought to originate in a cerebello-thalamocortical network. Molecular neuroimaging has helped clarify metabolic aspects and neurotransmitter influences on the main tremor network. In ET, recent positron emission tomography (PET) studies are built on previous knowledge and highlighted the possibility of investigating metabolic brain changes after treatments, in the attempt to establish therapeutic biomarkers. In PD, molecular neuroimaging has advanced the knowledge of non-dopaminergic determinants of tremor, providing insights into serotonergic and noradrenergic contributions.

Summary Recent advances have greatly extended the knowledge of tremor pathophysiology and it is now necessary to translate such knowledge in more efficacious treatments for this symptom.
\end{abstract}

Keywords Tremor $\cdot$ Molecular neuroimaging $\cdot$ Parkinson's disease $\cdot$ Essential tremor

\section{Introduction}

Tremor is an involuntary, rhythmic, oscillatory movement of a body part. According to the latest consensus statement on the classification of tremor of the International Parkinson and Movement Disorder Society, tremor may be classified along two axes, i.e. clinical features (axis 1) and etiology (axis 2) [1]. The most common tremor etiologies are essential tremor (ET) and parkinsonian tremor. While ET is classically characterized by bilateral upper limb postural and kinetic (i.e. action) tremor without other neurological signs,

This article is part of the Topical Collection on Neuroimaging

Jacopo Pasquini

jacopo.pasquini@newcastle.ac.uk

1 Department of Pathophysiology and Transplantation, University of Milan, Milan, Italy

2 Clinical Ageing Research Unit, Newcastle University, Campus for Ageing \& Vitality, Westgate Road, Newcastle upon Tyne NE4 5PL, UK

3 Department of Clinical and Experimental Medicine, University of Pisa, Pisa, Italy

4 Neurodegenerative Diseases Center, Azienda Ospedaliero Universitaria Pisana, Pisa, Italy parkinsonian tremor is classically at rest and accompanied by bradykinesia. Of note, segregation between essential tremor and parkinsonian tremor is not always clinically obvious, as essential tremor patients may present additional mild neurological signs, such as a rest tremor component, dystonic posturing, difficult tandem walking etc., a phenotype named ET plus. Furthermore, ET patients may also have an increased risk of developing Parkinson's disease (PD); this association has been thoroughly reviewed in [2]. From a neurophysiological point of view, parkinsonian rest tremor is typically a $4-6-\mathrm{Hz}$ tremor, while action tremor of ET is a $5-8-\mathrm{Hz}$ tremor [3]. Other, less frequent forms of tremor include dystonic tremors, characterized by the association with dystonia, and Holmes tremor, usually associated with other brainstem or thalamic localizing signs.

In this review, we will highlight the pathophysiological and clinical aspects of tremor as investigated through molecular neuroimaging, such as positron emission tomography (PET) and single-photon emission tomography (SPECT). We will also refer non-systematically to other techniques, such as magnetic resonance imaging (MRI) and neurophysiological studies of tremor. The major focus of this review will be on ET and parkinsonian tremor. Brief paragraphs will be dedicated to dystonic tremor and Holmes tremor. 


\section{Search Strategy}

Pubmed/MEDLINE database was interrogated. Search words were "tremor" and: "molecular neuroimaging", "single photon emission tomography", "positron emission tomography". Articles written in English investigating tremor in humans through molecular neuroimaging were selected; additional articles with these characteristics were extracted from the references.

\section{Molecular Neuroimaging Correlates of Essential Tremor}

The mechanism of tremor generation in ET is only partially understood and thought to be due to a network dysfunction involving the cerebellum, thalamus, motor cortex and perhaps the inferior olivary complex and the red nucleus [4]. Furthermore, ET itself is a dynamic disease and it is currently debated whether it is only characterized by an abnormal activity in the tremor network or it is part of a broader neurodegenerative spectrum $[5,6]$. The current main medication available for ET are beta-blockers, such as propranolol, and GABA-enhancing drugs such as primidone, benzodiazepines and gabapentin [7]. Different mechanisms and neurotransmitter systems influence the main tremor network and molecular imaging approaches have been used to investigate pathophysiological aspects of ET. Molecular neuroimaging approaches in essential tremor have explored cerebral blood flow, metabolism and neurotransmitter binding sites.

\section{Cerebral Blood Flow and Metabolism in Essential Tremor}

Early studies mostly focused on investigating alterations of cerebral blood flow in various brain regions included in the tremor network. To investigate regional blood flow, PET studies used radiolabelled water (e.g. $\mathrm{H}_{2}{ }^{15} \mathrm{O}$ ) or carbon dioxide $\left(\mathrm{C}^{15} \mathrm{O}_{2}\right)$ and SPECT studies used ${ }^{99 \mathrm{~m}}$ Tc-HMPAO or ${ }^{99 \mathrm{~m}}$ Tc-ethyl-cysteinate dimer $\left({ }^{99 \mathrm{~m}} \mathrm{Tc}-\mathrm{ECD}\right)$. Initially, the rationale of studying the tremor network through regional cerebral blood flow was to establish the central origin of essential tremor and to study its cerebral correlates. Of note, these studies included no more than 11 patients and 10 controls each. A common finding in ET was a bilateral increase in cerebellar regional blood flow, indicating increased cerebellar activity, at rest and when posturing compared to controls [8-12]. Notably, it was also shown that bilateral increase of cerebellar blood flow was observed only in ET while posturing ("tremor task") but not with passive flexion-extension of the wrist at tremor frequency ("proprioceptive task"), indicating that cerebellar activation is related to tremulous activity and not to a proprioceptive feedback. One study that employed a wider field of view also found significant increases in activity of the red nuclei and thalami during tremulous activity in patients with ET [10].

Glucose metabolism has also been explored, although to a lesser extent. One of the earliest ${ }^{18} \mathrm{~F}$-fluorodeoxyglucose (FDG) PET studies reported an increase in medullary and thalamic, but not cerebellar, glucose metabolism in patients with ET compared to controls, suggesting an important role of the inferior olivary nucleus in generating tremor in ET [13]. More recent studies highlighted reductions in cortical frontal, temporal, precuneus and occipital metabolism in ET patients compared to controls, while they showed heterogeneous results regarding cerebellum glucose metabolism $[14,15]$. Recently, two studies have employed FDG-PET to monitor regional glucose metabolism changes after interventions for ET. In one study, FDG-PET was conducted before and after gamma knife surgery of the ventral intermediate nucleus (Vim) of the thalamus in 42 ET patients. More than 1 year after surgery, a significant decrease in glucose metabolism was found within the left thalamus, the right cerebellum and frontal and temporal areas that were identified as hypermetabolic compared to controls before treatment [16•]. Furthermore, decreased temporo-occipital metabolism at baseline was predictive of a lack of tremor response after surgery. This study highlighted the remote effect of a lesion inside the tremor network and the possibility of investigating metabolic biomarkers that may help predict the response to treatments. Another small pilot trial measured brain metabolic activity with FDG-PET in 5 ET patients enrolled in an open-label trial with transcutaneous afferent patterned stimulation (TAPS) [17•], a noninvasive electrical stimulation of peripheral nerves at the wrist known to reduce hand tremor in ET [18]. Reduction in tremor amplitude was on average $73 \%$ after treatment. After 90 days of treatment, compared to baseline, FDG-PET revealed increased metabolism in the cerebellar hemisphere ipsilateral to the stimulation and hypometabolism contralaterally, and a moderate-strong correlation was found between the change in tremor severity and the change in FDG uptake in the hypermetabolic hemicerebellum. Some cortical areas, including frontal, occipital and parietal showed decreased metabolism after treatment. The reduction of metabolism in some cortical areas and in one cerebellar hemisphere seems consistent between these two interventional studies [16•, 17•]. Therefore, FDG-PET appears an appropriate technique to investigate cerebral metabolic changes after interventions for ET and future studies are needed to investigate metabolic correlates of ET treatments that could yield potential disease and therapeutic biomarkers. 
Receptor and Neurotransmitter Imaging in Essential Tremor

Receptor imaging in ET has mostly been focused on dopaminergic pathways. Studies were initially conducted to explore the relationship between ET and PD and have provided a great wealth of data about the pathophysiology of tremor in these conditions. The majority of these studies did not find significant reductions in striatal dopaminergic markers in patients with a classic essential tremor presentation compared to controls (Table 1) [19-27]. Conversely, dopamine transporter imaging in patients with atypical tremor (e.g. unilateral presentation or presence of a rest component) and/or additional "soft" parkinsonian signs (e.g. mild rigidity or bradykinesia) highlighted a blurred territory between ET and PD. Indeed, some patients with atypical features and additional parkinsonian signs may demonstrate striatal DaT reductions comparable to those with PD and usually convert to overt PD after a few months or years, while patients with normal striatal DaT will retain their tremulous phenotype over the same period of time (Table 2) [19, 28-33]. These studies highlight the heterogenous nature of the underlying pathophysiological process in patients presenting with mixed and atypical tremor presentations. However, while reduced striatal DaT represents a biomarker of PD in these patients, it is currently unknown whether patients with atypical tremors and normal striatal DaT have an increased risk of developing PD or other neurodegenerative diseases in the longer term. In the future, large longitudinal studies with a detailed phenotyping are needed to clarify whether patients with ET have an increased risk of developing PD and whether any possible associated risk factors and biomarkers can be identified.

A few studies have provided investigations about the state of other neurotransmitter systems in ET, such as the GABAergic and the serotonergic systems. Reduced GABAergic function in the tremor network is thought to play an

Table 1 Summary of selected studies investigating the state of the nigro-striatal dopaminergic markers in essential tremor and Parkinson's disease

\begin{tabular}{|c|c|c|c|}
\hline Author, year & Technique & Cohort & Findings \\
\hline Brooks et al. (1992) [19] & ${ }^{18} \mathrm{~F}$-DOPA PET & $\begin{array}{l}20 \text { isolated PT } \\
11 \text { isolated RT } \\
16 \mathrm{PD} \\
20 \mathrm{HCs}\end{array}$ & $\begin{array}{l}2 \text { of } 20 \text { isolated PT had subnormal putamen }{ }^{18} \mathrm{~F} \text {-DOPA } \\
\text { activity, one of whom in the PD range and later became } \\
\text { akinetic. } 18 \text { of } 20 \text { had normal tracer activity } \\
\text { All isolated RT patients had putamen }{ }^{18} \mathrm{~F} \text {-DOPA activity in } \\
\text { the PD range }\end{array}$ \\
\hline Asenbaum et al. (1998) [26] & ${ }^{123} \mathrm{I}-\beta$-CIT SPECT & $\begin{array}{l}32 \text { ET (without soft signs) } \\
29 \text { PD (HY stage 1) } \\
30 \text { HCs }\end{array}$ & $\begin{array}{l}\text { ET: normal striatal uptake compared to controls } \\
\text { PD: reduced striatal uptake compared to controls }\end{array}$ \\
\hline Benamer et al. (2000) [21] & ${ }^{123}$ I-FP-CIT SPECT & $\begin{array}{l}27 \mathrm{ET} \\
158 \text { parkinsonism } \\
35 \mathrm{HCs}\end{array}$ & $\begin{array}{l}\text { ET: } 25 \text { of } 27 \text { scans visually graded as normal } \\
\text { Parkinsonism: } 150 \text { of } 158 \text { visually graded as abnormal } \\
\text { HC: } 33 \text { of } 35 \text { visually graded as normal }\end{array}$ \\
\hline $\begin{array}{l}\text { Parkinson Study } \\
\text { Group (2000) [20] }\end{array}$ & ${ }^{123} \mathrm{I}-\beta$-CIT SPECT & $\begin{array}{l}14 \mathrm{ET} \\
43 \mathrm{PD} \\
17 \mathrm{PSP} \\
22 \mathrm{HCs}\end{array}$ & $\begin{array}{l}\text { Visual inspection agreed with clinical diagnosis in: } 98 \% \text { of } \\
\text { parkinsonism, } 83 \% \text { of ET/HCs } \\
\text { Quantitative analysis did not find differences between ET } \\
\text { and HCs (but found lower uptake in ET patients visually } \\
\text { diagnosed as parkinsonism) }\end{array}$ \\
\hline Isaias et al. (2010) [24] & $\begin{array}{l}{ }^{123} \text { I-FP-CIT SPECT } \\
{ }^{99} \text { Tc-ECD SPECT } \\
\text { (prefusion imaging) }\end{array}$ & $\begin{array}{l}20 \mathrm{ET} \\
13 \mathrm{PD} \\
23 \mathrm{HCs}\end{array}$ & $\begin{array}{l}\text { ET: normal striatal FP-CIT uptake at baseline and after } \\
3 \text { years. Some ET patients have caudate uptake lower than } \\
\text { controls } \\
\text { Tremor network analysis with perfusion imaging revealed } \\
\text { significant and discriminant differences between ET and } \\
\text { PD }\end{array}$ \\
\hline Roselli et al. (2010) [25] & $\begin{array}{l}{ }^{123} \text { I-FP-CIT SPECT } \\
\text { (dopamine and } \\
\text { serotonin transporter } \\
\text { imaging) }\end{array}$ & $\begin{array}{l}11 \mathrm{ET} \\
15 \mathrm{PD}, 16 \mathrm{LBD}, 10 \mathrm{PSP} \\
9 \mathrm{HC}\end{array}$ & $\begin{array}{l}\text { ET: normal striatal and midbrain raphe FP-CIT uptake } \\
\text { PD: reduced striatal and normal midbrain raphe FP-CIT } \\
\text { uptake }\end{array}$ \\
\hline Di Giuda et al. (2012) [23] & ${ }^{123}$ I-FP-CIT SPECT & $\begin{array}{l}15 \mathrm{ET} \\
21 \mathrm{PD} \\
17 \mathrm{HCs}\end{array}$ & $\begin{array}{l}\text { ET: normal striatal uptake. Severity of anxiety symptoms } \\
\text { inversely correlated with left caudate DAT } \\
\text { PD: caudate DAT inversely correlated with depressive } \\
\text { symptoms }\end{array}$ \\
\hline
\end{tabular}

Abbreviations: $E T$, essential tremor; $H C$, healthy controls; $H Y$, Hoehn and Yahr scale: PET, positron emission tomography; $P D$, Parkinson's disease; $P T$, postural tremor; $R T$, rest tremor; $S P E C T$, single-photon emission computed tomography

Radioligands: ${ }^{18}$ F-DOPA: ${ }^{18}$ F-fluoro-L-dopa; ${ }^{123}$ I-beta-CIT SPECT: ${ }^{123} \mathrm{I}$-2 $\beta$-carbomethoxy-3 $\beta$-(4-iodophenyl)tropane; ${ }^{123} \mathrm{I}$-FP-CIT SPECT:

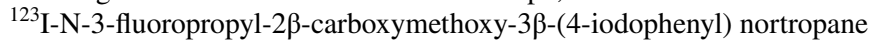


Table 2 Summary of selected studies investigating the state of the nigro-striatal dopaminergic markers in patients with a tremor presentation and atypical features (e.g. unilateral or markedly asymmetrical

\begin{tabular}{|c|c|c|c|}
\hline Author, year & Technique & Cohort & Findings \\
\hline $\begin{array}{l}\text { Lee et al. (1999) } \\
\text { [27] }\end{array}$ & ${ }^{123}$ I-IPT SPECT & $\begin{array}{l}9 \text { isolated PT } \\
6 \mathrm{PT} \text { and RT } \\
11 \mathrm{PD} \\
21 \mathrm{HCs}\end{array}$ & $\begin{array}{l}\text { Isolated PT: normal striatal uptake } \\
\text { PT and RT: uptake significantly lower than } \\
\text { HCs and similar to PD } \\
\text { PD: reduced striatal uptake }\end{array}$ \\
\hline $\begin{array}{l}\text { Schwartz } \\
\text { et al. (2004) [28] }\end{array}$ & ${ }^{123}$ I-FP-CIT SPECT & $\begin{array}{l}10 \text { ET with impairment at visuo-motor } \\
\text { testing }\end{array}$ & $\begin{array}{l}\text { Decreased striatal uptake in } 8 \text { of } 10 \text { patients. } \\
\text { Striatal uptake correlated with visuo-motor } \\
\text { testing score }\end{array}$ \\
\hline $\begin{array}{l}\text { Ceravolo } \\
\text { et al. (2008) [29] }\end{array}$ & ${ }^{123}$ I-FP-CIT SPECT & $\begin{array}{l}61 \text { patients with isolated atypical tremor } \\
\text { (unilateral postural, rest o mixed tremor) }\end{array}$ & $\begin{array}{l}\text { Rest tremor: abnormal DaT in } 76 \% \text {; of these, } \\
75 \% \text { progressed to PD after } 2 \text { years } \\
\text { Postural tremor: abnormal DaT in } 50 \% \text {; of } \\
\text { these, } 50 \% \text { progressed to PD after } 2 \text { years } \\
\text { Mixed tremor: abnormal DaT in } 50 \% \text {; of } \\
\text { these, } 60 \% \text { progressed to PD after } 2 \text { years } \\
\text { No patient with normal baseline DaT pro- } \\
\text { gressed to PD after } 2 \text { years }\end{array}$ \\
\hline $\begin{array}{l}\text { Novellino } \\
\text { et al. (2009) [33] }\end{array}$ & $\begin{array}{l}{ }^{123} \mathrm{I} \text {-FP-CIT SPECT } \\
{ }^{123} \text { I-MIBG cardiac SPECT }\end{array}$ & $\begin{array}{l}10 \mathrm{ET} \\
22 \text { mixed }(\mathrm{RT}+\mathrm{PT}) \text { tremor }+ \text { mild extrapyr } \\
\text { features } \\
20 \mathrm{PD} \\
18 \mathrm{HCs}\end{array}$ & $\begin{array}{l}\text { ET: normal striatal and cardiac uptake in all } \\
\text { patients } \\
\text { PD: reduced striatal and cardiac uptake in all } \\
\text { patients } \\
\text { Mixed tremor: } 73 \% \text { reduced striatal uptake; of } \\
\text { these, } 50 \% \text { reduced cardiac MIBG uptake }\end{array}$ \\
\hline $\begin{array}{l}\text { De Verdal } \\
\text { et al. (2013) [30] }\end{array}$ & ${ }^{123}$ I-FP-CIT SPECT & 33 mixed tremor $(\mathrm{RT}+\mathrm{PT} / \mathrm{KT})$ & $\begin{array}{l}\text { Striatal DaT reduced in } 76 \% \text { of patients. No } \\
\text { significant differences in tremor character- } \\
\text { istics between patients with and without } \\
\text { nigrostriatal denervation }\end{array}$ \\
\hline $\begin{array}{l}\text { Coria et al. (2012) } \\
\text { [31] }\end{array}$ & ${ }^{123}$ I-FP-CIT SPECT & $\begin{array}{l}167 \text { isolated action tremor (without RT or } \\
\text { bradykinesia) }\end{array}$ & $\begin{array}{l}\text { Asymmetric tremor in } 74 \% \text { of patients. Posi- } \\
\text { tive family history in } 45 \% \text { of patients } \\
\text { Visually abnormal striatal DaT in } 68 \% \text { of } \\
\text { patients; of these } 91 \% \text { had DaT in the range } \\
\text { of PD. Onset of tremor }>50 \text { years and asym- } \\
\text { metrical distribution of tremor were predic- } \\
\text { tive of nigrostriatal denervation }\end{array}$ \\
\hline $\begin{array}{l}\text { Waln et al. (2015) } \\
\text { [32] }\end{array}$ & ${ }^{123}$ I-FP-CIT SPECT & $\begin{array}{l}22 \text { ET "pure" } \\
9 \text { ET-P (ET + } 1 \text { PD cardinal sign }) \\
8 \text { ET + PD } \\
13 \text { HCs }\end{array}$ & $\begin{array}{l}\text { ET “pure" and ET-P: normal DaT uptake by } \\
\text { visual analysis. ET + PD visually abnormal } \\
\text { Semiquantitative analysis: ET "pure" and } \\
\text { ET-P had normal mean putamen and caudate } \\
\text { SBR; non-significant reduction in caudate } \\
\text { of ET compared to controls. ET-PD had } \\
\text { reduced caudate and putamen SBR }\end{array}$ \\
\hline
\end{tabular}

Abbreviations: $E T$, essential tremor; $H C s$, healthy controls; $H Y$, Hoehn and Yahr scale; $K T$, kinetic tremor; $P E T$, positron emission tomography: $P D$, Parkinson's disease; $P T$, postural tremor; $R T$, rest tremor; SPECT, single-photon emission computed tomography.

Radioligands: ${ }^{123} \mathrm{I}-\mathrm{N}-\left(3\right.$-iodopropen-2-yl)-2b-carbomethoxy-3b-(4-chlorophenyl) tropane; ${ }^{123} \mathrm{I}-\mathrm{FP}-\mathrm{CIT} \quad$ SPECT: ${ }^{123} \mathrm{I}-\mathrm{N}-3$-fluoropropyl-2 $\beta$ carboxymethoxy-3 $\beta$-(4-iodophenyl) nortropane. ${ }^{123}$ I-MIBG: ${ }^{123}$ I-meta-iodobenzylguanidine.

important role in ET and is likely the basis of its improvement with GABAergic medication. Pathological studies have shown cerebellar degenerative changes, including a decrease in the number of GABAergic Purkinje cells [34]. ${ }^{11} \mathrm{C}$-flumazenil, a $\mathrm{GABA}_{\mathrm{A}}$ receptor ligand, PET was used in one study to assess the state of the GABAergic system in 8 ET patients and 11 controls. Increased tracer binding, corresponding to an increased $\mathrm{GABA}_{\mathrm{A}}$ receptor availability, was found in the ventrolateral thalamus in the ventral intermediate (Vim) nucleus, dentate nucleus and premotor cortex, presentation) and/or additional "soft" parkinsonian signs (e.g. rest tremor, mild rigidity or bradykinesia) 
45 ET patients and 35 controls, although a significant asymmetry in GABA content was found among ET patients only [37]. Overall, only a few molecular neuroimaging studies have investigated the "GABAergic hypothesis" in essential tremor; thus, further characterization may help clarify related pathophysiological aspects.

Finally, only two small imaging studies have investigated the state of the raphe serotonergic nuclei through SERT tracers, and they did not highlight changes compared to controls or correlation to tremor scores $[36,38]$.

\section{Molecular Neuroimaging Correlates of PD Tremor}

PD is characterized by rest, postural and kinetic tremors; a subtype of postural tremor, re-emergent tremor, may also be present $[1,39]$.

Rest tremor is the most common type of tremor in PD and thought to be generated by abnormal activity in the basal ganglia that induces tremulous activity in a cerebellothalamo-cortical tremor network [40]. More recent evidence suggests that re-emergent tremor, i.e. a postural tremor that occurs when holding a posture for a sufficient period of time, shares the same mechanism with rest tremor [41, 42]. Molecular neuroimaging has investigated the influence of perfusion, metabolic and neurotransmitter dysfunctions, mainly dopamine, serotonin and noradrenaline, on rest tremor.

\section{Cerebral Blood Flow and Metabolism in PD Tremor}

Perfusion abnormalities studies were among the first to investigate PD tremor. These small studies in patients with deep brain stimulation (DBS) of the ventral intermediate nucleus (Vim) of the thalamus found cerebellar blood flow increases during tremulous activity that was reversible upon successful DBS activation and subsequent tremor arrest [43-45]. Interestingly, this finding resembles cerebellar blood flow abnormalities observed in essential tremor.

The study of cerebral metabolism through FDG-PET has revealed interesting findings in PD tremulous phenotypes. PD shows a classically altered metabolic signature, named the PD-related pattern (PDRP), characterized by increased pallidothalamic and ponto-cerebellar metabolism and relative reductions in premotor and posterior parietal (associative) cortical regions [46-48]. Notably, patients with a tremulous phenotype also show a different metabolic signature named PD-related tremor pattern (PDTP) [49]. One study in nine tremor-dominant PD patients treated with VimDBS showed that the tremor-related pattern was characterized by metabolic increases in the cerebellum, the primary motor cortex, and to a lesser extent in the striatum [50].
This pattern was present before surgery and its expression was significantly reduced by Vim stimulation. Furthermore, the hemispheric intensity of pattern expression at baseline was associated with contralateral accelerometric measurements of tremor amplitude, and in an independent sample PDTP expression correlated with UPDRS tremor scores. This observation suggests that tremor itself, and not just the tremulous phenotype, is related to the expression of the tremor-related network. A subsequent multitracer study with FDG and ${ }^{18}$ FDOPA PET showed that higher dopaminergic terminal availability in the striatum of tremor-dominant patients was also associated with a higher glucose metabolic rate compared to akinetic-rigid patients [51]. Overall, metabolic imaging in PD has provided evidence that specific alterations may be identified between different phenotypes, that a metabolic signature, i.e. the PD tremor-related pattern, is typical of tremulous PD, and that the expression of this signature is also associated with tremor severity. A summary of the studies investigating metabolic and other nondopaminergic correlates of parkinsonian tremor is shown in Table 3.

\section{Receptor Imaging in PD Tremor}

Neurotransmitter dysfunction has been extensively investigated in PD tremor especially through dopaminergic imaging. Nigral degeneration and associated striatal dopaminergic loss are the hallmark of PD and thought to be necessary for the generation of PD tremor. However, as highlighted in the previous paragraph, phenotypic expression of rest tremor may be sometimes unrelated to nigrostriatal degeneration, as it is in some cases of essential tremor with rest tremor. A further complication in establishing the pathophysiology of PD tremor is the fact that its clinical severity seems unrelated to the degree of nigrostriatal denervation, as opposed to bradykinesia and rigidity [52-61]. In one study, accelerometer-based measurement of tremor severity failed to find an association with contralateral striatal DaT [62]. However, the index of asymmetry of tremor power and striatal DaT were associated, indicating a relationship between higher tremor severity and nigrostriatal denervation in the more affected hemisphere. A recent study has employed surface EMG and tri-axial accelerometers in order to establish whether a more precise quantification of tremor may reflect dopaminergic denervation [63]. A series of recordings in various settings (e.g. at rest, posturing, index-to-nose movements, with and without mental or motor distraction) was carried out and, quite strikingly, tremor power recorded by different sensors in many resting conditions were correlated with contralateral striatal DaT availability. It must be mentioned that total UDPRS III tremor scores also correlated with contralateral striatal uptake, a finding that is in contrast with many previous studies. Therefore, we cannot exclude 
Table 3 Summary of selected studies investigating non-dopaminergic correlates of PD tremor

\begin{tabular}{|c|c|c|c|}
\hline Author, year & Technique & Cohort & Findings \\
\hline \multicolumn{4}{|c|}{ PET-FDG metabolic investigations } \\
\hline $\begin{array}{l}\text { Antonini } \\
\text { et al. (1998) [49] }\end{array}$ & ${ }^{18}$ FDG PET & $\begin{array}{l}8 \mathrm{PD} \text { with and } 8 \text { without tremor in off- } \\
\text { state } \\
10 \mathrm{HCs}\end{array}$ & $\begin{array}{l}\text { PD with tremor had increased meta- } \\
\text { bolic rate in a network comprising the } \\
\text { thalamus, pons, and premotor cortical } \\
\text { regions, a network that was called the } \\
\text { PD related tremor pattern (PDTP) } \\
\text { While all patients with PD usually express } \\
\text { metabolic alterations in a metabolic net- } \\
\text { work called PDRP, tremulous phenotype } \\
\text { also require the expression of the PDTP }\end{array}$ \\
\hline $\begin{array}{l}\text { Lozza et al. (2002) } \\
\text { [89] }\end{array}$ & ${ }^{18}$ FDG PET & 17 non-demented PD in the ON state & $\begin{array}{l}\text { Bradykinesia scores positively correlated } \\
\text { with putaminal and pallidal metabolic } \\
\text { rates. Tremor scores negatively cor- } \\
\text { related with putamen and cerebellar } \\
\text { vermis metabolic rate }\end{array}$ \\
\hline $\begin{array}{l}\text { Mure et al. (2011) } \\
\text { [50] }\end{array}$ & ${ }^{18}$ FDG PET & $\begin{array}{l}9 \text { tremor dominant PD patients scanned } \\
\text { at baseline and during Vim-DBS }\end{array}$ & $\begin{array}{l}\text { Baseline metabolic pattern revealed a PD } \\
\text { tremor-related network composed of cer- } \\
\text { ebellum/dentate nuclei, primary motor } \\
\text { cortex and striatum. Vim stimulation } \\
\text { resulted in consistent reductions in this } \\
\text { pattern expression. Without stimulation, } \\
\text { pattern expression values correlated with } \\
\text { accelerometric measurements of tremor } \\
\text { amplitude }\end{array}$ \\
\hline $\begin{array}{l}\text { Eggers et al. (2014) } \\
\text { [51] }\end{array}$ & $\begin{array}{l}{ }^{18} \mathrm{~F}-\mathrm{DOPA} \\
{ }^{18} \mathrm{FDG} \text { PET }\end{array}$ & 64 PD patients (32 TD) & $\begin{array}{l}\text { Higher putamen and caudate metabolism } \\
\text { in tremulous PD vs akinetic-rigid PD. } \\
\text { Striatal }{ }^{18} \text { F-DOPA and FDG activity } \\
\text { were closely correlated }\end{array}$ \\
\hline \multicolumn{4}{|c|}{ Serotonergic pathways investigations } \\
\hline $\begin{array}{l}\text { Doder et al. (2003) } \\
\text { [69] }\end{array}$ & $\begin{array}{l}{ }^{11} \mathrm{C}-\mathrm{WAY} 100,635 \mathrm{PET}\left(5 \mathrm{HT}_{1 \mathrm{~A}}\right. \\
\text { receptor ligand) }\end{array}$ & $\begin{array}{l}23 \mathrm{PD} \\
8 \mathrm{HCs}\end{array}$ & $\begin{array}{l}\text { UDPRS total and rest tremor scores, but } \\
\text { not bradykinesia and rigidity, were } \\
\text { inversely correlated with tracer binding } \\
\text { in midbrain raphe }\end{array}$ \\
\hline $\begin{array}{l}\text { Caretti et al. (2008) } \\
\text { [90] }\end{array}$ & ${ }^{123}$ I-beta-CIT (SERT ligand) & $\begin{array}{l}32 \mathrm{PD} \text { ( } 23 \text { scanned also after } 17 \text { months) } \\
13 \mathrm{HCs}\end{array}$ & $\begin{array}{l}\text { PD with tremor have significantly reduced } \\
\text { uptake in thalamus, representing mostly } \\
\text { SERT availability, compared to PD } \\
\text { without tremor; no differences at follow } \\
\text { up (indicating greater declines in PD } \\
\text { without tremor) }\end{array}$ \\
\hline $\begin{array}{l}\text { Loane et al. (2013) } \\
\text { [72] }\end{array}$ & ${ }^{11}$ C-DASB PET (SERT ligand) & $\begin{array}{l}12 \text { TD-PD } \\
12 \text { AR-PD } \\
12 \mathrm{HCs}\end{array}$ & $\begin{array}{l}{ }^{11} \mathrm{C} \text {-DASB uptake in putamen, caudate } \\
\text { and raphe nuclei was negatively corre- } \\
\text { lated with severity of action tremor, but } \\
\text { not with rest tremor in TD-PD. TD-PD } \\
\text { also showed SERT reductions in caudate } \\
\text { and putamen compared to AR-PD }\end{array}$ \\
\hline $\begin{array}{l}\text { Qamhawi } \\
\text { et al. (2015) [70] }\end{array}$ & ${ }^{123}$ I-FP-CIT SPECT (SERT ligand) & $\begin{array}{l}345 \text { de novo PD } \\
145 \mathrm{HCs}\end{array}$ & $\begin{array}{l}{ }^{123} \text { I-FP-CIT raphe uptake, representa- } \\
\text { tive of SERT availability, was inversely } \\
\text { associated with rest tremor severity in } \\
\text { the whole cohort and in a subgroup of } \\
\text { tremulous patients }\end{array}$ \\
\hline $\begin{array}{l}\text { Pasquini } \\
\text { et al. }(2018)[71 \bullet]\end{array}$ & ${ }^{123}$ I-FP-CIT SPECT (SERT ligand) & $\begin{array}{l}378 \text { de novo PD } \\
145 \mathrm{HCs}\end{array}$ & $\begin{array}{l}\text { In TD patients rest tremor severity was } \\
\text { inversely associated with raphe SERT } \\
\text { at baseline and after two years. More } \\
\text { severe raphe dysfunction coupled with } \\
\text { less severe putaminal dopaminergic den- } \\
\text { ervation was associated with higher rest } \\
\text { tremor scores and reduced rest tremor } \\
\text { response to dopaminergic therapy }\end{array}$ \\
\hline
\end{tabular}


Table 3 (continued)

\begin{tabular}{|c|c|c|c|}
\hline Author, year & Technique & Cohort & Findings \\
\hline \multicolumn{4}{|c|}{ Noradrenergic pathways investigations } \\
\hline $\begin{array}{l}\text { Isaias et al. (2011) } \\
{[74]}\end{array}$ & ${ }^{123}$ I-FP-CIT SPECT & $82 \mathrm{PD}$ & $\begin{array}{l}{ }^{123} \text { I-FP-CIT binding in pons, represent- } \\
\text { ing locus coeruleus noradrenergic } \\
\text { transporter, was significantly higher in } \\
\text { PD patients than controls. No differ- } \\
\text { ences between patients with and without } \\
\text { tremor }\end{array}$ \\
\hline $\begin{array}{l}\text { Nahimi et al. (2018) } \\
\text { [75] }\end{array}$ & ${ }^{11}$ C-MeNER PET (NET ligand) & $\begin{array}{l}15 \mathrm{PD} \\
10 \mathrm{HCs}\end{array}$ & $\begin{array}{l}\text { Tracer uptake significantly reduced in red } \\
\text { nucleus and thalamus of PD patients. } \\
\text { Tremor occurrence was associated with } \\
\text { higher thalamic tracer binding in PD. } \\
\text { Tremor severity not associated with } \\
\text { tracer binding in any region }\end{array}$ \\
\hline $\begin{array}{l}\text { Kinnerup } \\
\text { et al. }(2021) \\
{[76 \bullet]}\end{array}$ & ${ }^{11} \mathrm{C}-\mathrm{MeNER}$ PET (NET ligand) & $\begin{array}{l}65 \mathrm{PD} \text { ( } 28 \text { tremulous) } \\
28 \mathrm{HCs}\end{array}$ & $\begin{array}{l}\text { Tracer uptake was significantly higher in } \\
\text { LC and thalamus of tremulous patients. } \\
\text { In tremulous patients LC tracer uptake } \\
\text { was similar to controls, while in the } \\
\text { raphe was significantly reduced. In } \\
\text { non-tremulous patients, tracer uptake } \\
\text { was significantly reduced in all regions } \\
\text { compared to controls } \\
\text { Rest tremor severity was associated with } \\
\text { higher NET availability in median raphe, } \\
\text { thalamus and red nuclei }\end{array}$ \\
\hline
\end{tabular}

Abbreviations: $A R$, akinetic-rigid; $H C s$, healthy controls; NET, noradrenaline transporter; $P D$, Parkinson's disease; $P E T$, positron emission tomography; SERT, serotonin transporter; SPECT, single-photon emission tomography; UPDRS, Unified Parkinson's Disease Rating Scale; TD, tremor dominant

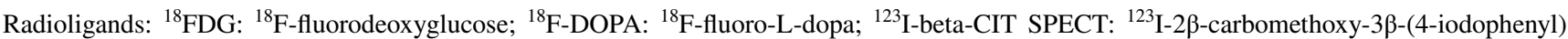

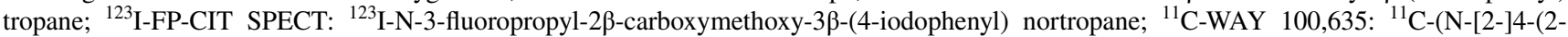
methoxyphenyl)-1-piperazinyl]ethyl]-N-(2- pyridinyl)cyclohexanecarboxamide); ${ }^{11} \mathrm{C}$-DASB: ${ }^{11} \mathrm{C}-3$-amino-4-(2-dimethylaminomethyl-phenylsulfanyl)benzonitrile; ${ }^{11} \mathrm{C}$-MeNER: ${ }^{11} \mathrm{C}$-methylreboxetine

that this finding is specifically related to the cohort studied and needs replication in different and larger cohorts. Nonetheless, a more precise evaluation of tremor, such as that carried out by Fois and colleagues, may reveal previously undetected findings. Although in previous studies severity of nigrostriatal denervation and tremor were not associated, differences in tremor-dominant (TD) and akintic-rigid (AR) patients could be identified. Indeed, it is a common finding that patients with a tremulous phenotype have a significantly more preserved striatal DaT availability $[64,65]$. It has also been shown that a different pattern of nigrostriatal denervation may be visually spotted in the two phenotypes: in one study Eggers and colleagues showed that scans of TD patients are more frequently associated with an "eagle wing" shape of striatal DaT availability [66]. This pattern resembles that of pathological descriptions of tremulous patients with a higher degree of degeneration in the dopaminergic retrorubral area (A8) that projects to the lateral putamen[67]. Pallidal dopaminergic denervation has also been hypothesized to be involved in tremor generation. In a seminal paper on tremor pathophysiology, Helmich and colleagues used a multimodal approach to simultaneously study basal ganglia dopaminergic denervation, the cerebello-thalamo-cortical tremor network and quantitative tremor assessment [68]. In tremulous patients, pallidal DaT was lower in the most affected hemisphere compared to non-tremulous patients, and rest tremor severity correlated with pallidal, but not striatal, DaT. With fMRI, they also showed that while the basal ganglia were activated transiently at the onset of tremor episodes, activity in the cerebello-thalamo-cortical circuit covaried with tremor amplitude. Therefore, it was hypothesized that dopaminergic dysfunction in the basal ganglia is capable of driving the cerebello-thalamo-cortical circuit into tremor activity, in a "switch and dimmer" fashion.

The lack of correlation between nigrostriatal denervation and rest tremor severity, coupled with mixed responses to dopaminergic medication, has sparked research into nondopaminergic determinants of PD tremor, especially serotonin and noradrenaline. A first PET report on the serotonergic influence on tremor showed that a serotonin receptor $\left(5 \mathrm{HT}_{1 \mathrm{~A}}\right)$ ligand uptake in the midbrain raphe correlated inversely with total and rest tremor scores, but not with bradykinesia and rigidity [69]. It was hypothesized that degeneration of the serotonergic raphe nuclei projections could 
modulate the expression of tremor in PD. In two subsequent studies on the large cohort of the de novo PD patients from the Parkinson's Progressive Markers Initiative (PPMI), median raphe serotonin transporter (SERT) availability, assessed with ${ }^{123}$ I-FP-CIT SPECT, showed inverse correlations with tremor severity in the entire cohort of PD patients and in the tremulous subgroup [70,71•]. Furthermore, it was also shown that more severe raphe dysfunction, coupled with less severe dopaminergic denervation (i.e. a low raphe/putamen ratio), was associated with higher tremor scores and worse responses to dopaminergic medication [71•]. Therefore, while dopaminergic denervation appears necessary for rest tremor generation, the level of serotonergic dysfunction could modulate the intensity of tremor and its response to dopaminergic medication. It has also been suggested that the serotonergic system may modulate action tremor in PD. In a PET study involving 12 tremulous and 12 non-tremulous PD patients, it was shown that SERT availability in the putamen, caudate and raphe nuclei was inversely associated with the severity of action tremor, but not of rest tremor. This discrepancy on rest tremor compared to other studies may be due to the smaller number of patients included in the study that may have been underpowered to detect such association[72].

Noradrenergic dysfunction has been shown to influence tremor in PD. Central noradrenergic projections originate from the pontine locus coeruleus, known to be activated under stressful conditions. These are known in turn to exacerbate tremor [73]. Molecular neuroimaging of the noradrenergic system is a recent clinical research advancement and only a few studies have been carried out. One study investigated locus coeruleus noradrenergic transporter (NET) availability through ${ }^{123}$ I-FP-CIT SPECT but failed to show a relationship between locus coeruleus imaging abnormalities and tremor [74]. More recent PET investigations using ${ }^{11} \mathrm{C}$-methylreboxetine (11C-MeNER), a selective NET ligand, have highlighted different aspects of noradrenergic dysfunction in PD. It was shown that tremulous patients had significantly higher tracer uptake in the locus coeruleus and thalamus compared to non-tremulous patients. Tremulous patients had a locus coeruleus uptake similar to controls whereas the raphe was the only site with a significant reduction. Furthermore, rest tremor scores were positively associated with median raphe, thalamus and red nucleus tracer uptake [75, 76•]. Like neuropathological studies, these reports indicate that tremulous patients have a lower pathologic burden in the locus coeruleus compared to akinetic-rigid patients. It is interesting to note that the only binding site with reduced NET availability, and thus noradrenergic terminals, in tremulous patient was the median raphe, and that NET availability in the median raphe was associated with rest tremor severity. It is tempting to think that an interaction between the noradrenergic and the serotonergic ascending systems, especially in the tremor dominant form of PD, could modulate the expression of tremor. Multimodal and multitracer neuroimaging studies may help further clarify this issue.

Overall, molecular neuroimaging studies investigating PD tremor have helped clarify many pathophysiological aspects. One caveat in interpreting some of these studies is that tremulous phenotypes, rather than tremor itself, were investigated. Therefore, while many studies did establish associations with tremor severity, thus likely indicating a direct influence on tremor itself, others described associations with a specific phenotype. The latter must be interpreted with caution in terms of tremor pathophysiology, since abnormalities may be due to the phenotype itself, which may in turn be due a specific neuropathological pattern, rather than being directly associated with tremor.

\section{Other Types of Tremor}

\section{Dystonic Tremor}

Tremor may be a clinical feature associated with dystonia, and dystonia often presents with tremor. Furthermore, isolated tremor syndromes such as isolated head tremor may be forms of dystonia without clear abnormal posturing [77-79]. A recent study assessed striatal $\mathrm{DaT}$ availability in 14 patients with isolated head tremor and 14 controls [80•]. While all patients were found to have abnormal somatosensory temporal discrimination threshold (STDT), a feature usually associated with dystonia, normal dopaminergic transmission was documented. No correlation between nigrostriatal function and STDT was found, suggesting that neurophysiological measures associated with dystonia are not influenced by striatal DaT availability in this tremor syndrome. Conversely, the presence of striatal D2/D3 receptor abnormalities has been hypothesized in dystonia but it still subject to ongoing debate [81, 82].

\section{Holmes Tremor}

Holmes tremor is a syndrome of low frequency $(<5 \mathrm{~Hz})$ rest, postural and kinetic tremor that involves proximal and distal muscles [1]. It is generally thought as a network disorder involving lesions in the cerebello-thalamo-cortical or dentate-rubro-olivary pathways, and in the dopaminergic striatal system [83]. A recent study on the human brain connectome identified lesions causing Holmes tremor in a network that includes the red nucleus, internal globus pallidus, thalamus (ventralis oris posterior and pulvinar), cerebellum (vermis, lateral cerebellar cortex and flocculonodular) and the pontomedullary junction [84]. Another study revealed tremor amplitude-related activity in the sensorimotor cortex and cerebellar vermis in a patient with Holmes tremor 
caused by a microbleed near the right red nucleus that caused ipsilateral nigrostriatal dopaminergic denervation [85]. Nigrostriatal dopaminergic denervation is a variable finding in Holmes tremor and does not always correspond to a good levodopa responsiveness [83, 85-87]. Therefore, it has been suggested that lesions causing Holmes tremor do not localize to any single region, but instead localize to a functionally connected network [84]. The regional heterogeneity of the lesions causing Holmes tremor partially explains why some patients do not show nigrostriatal denervation or levodopa responsiveness. However, it is currently unknown how dopaminergic dysfunction influences the pathophysiology of Holmes tremor and the predictive factors of levodopa responsiveness. Multimodal neuroimaging studies including nigrostriatal dopaminergic imaging could help clarify this issue and select patients for the appropriate treatment, either pharmacological or surgical.

\section{Conclusions}

Tremor is a common hyperkinetic movement disorder with a complex pathophysiology. The most frequent tremor causes are essential tremor and Parkinson's disease tremor. A shared pathophysiological substrate of tremor likely lies in a cerebello-thalamo-cortical network capable of generating tremor oscillations and ultimately the involuntary movements. Neurotransmitter systems outside this network, such as dopamine, noradrenaline and serotonin, are able to influence the clinical manifestation of tremor. Molecular neuroimaging has provided great insights into the clinical correlates of tremor in ET and PD. In ET, cerebral blood flow and metabolic abnormalities have been characterized and they have demonstrated potential for translation into useful therapeutic

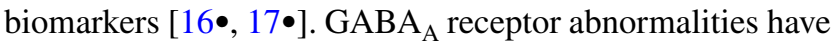
also been found and shown to be associated with tremor severity $[35,36]$. Conversely, studies investigating the state of the noradrenergic system are lacking. The recent availability of new noradrenaline transporter tracers that have already been used in PD may help clarify the influence of the noradrenergic system in ET. The dopaminergic system is not involved in classical ET, but may be degenerated in some isolated tremor syndromes with atypical features, and its investigation may thus be useful in establishing a differential diagnosis with PD. It is thought that ET patients may have an increased risk of $\mathrm{PD}$, but no predictive biomarkers exist in the absence of initial nigrostriatal denervation.

Rest tremor is one of the hallmarks of PD and it is thought to arise from basal ganglia dopaminergic dysfunction and its influence on the cerebello-thalamo-cortical network, a dysfunctional system that is thought to work in a "switch and dimmer" fashion [40]. The degeneration of the serotonergic and noradrenergic systems are also known to influence the manifestation of tremor in PD [68-70, 71•, 87]. Interestingly, tremulous PD also shows a typical metabolic signature, called the PD related tremor pattern, with increased glucose metabolic rates in cerebellum/dentate nucleus and primary motor cortex, and, to a lesser extent, the striatum [50].

Over the past few years, the pathophysiology of tremor has become increasingly clearer. However, both in ET and PD available medications may not be efficacious in all patients.

Therefore, there is a great need to transform an increasing wealth of knowledge about the mechanisms of tremor into new treatments.

Funding Jacopo Pasquini is supported by the European Academy of Neurology Research Fellowship program.

\section{Declarations}

Conflict of Interest Jacopo Pasquini and Roberto Ceravolo declare that they have no conflict of interest.

Human and Animal Rights and Informed Consent This article does not contain any studies with human or animal subjects performed by any of the authors.

Open Access This article is licensed under a Creative Commons Attribution 4.0 International License, which permits use, sharing, adaptation, distribution and reproduction in any medium or format, as long as you give appropriate credit to the original author(s) and the source, provide a link to the Creative Commons licence, and indicate if changes were made. The images or other third party material in this article are included in the article's Creative Commons licence, unless indicated otherwise in a credit line to the material. If material is not included in the article's Creative Commons licence and your intended use is not permitted by statutory regulation or exceeds the permitted use, you will need to obtain permission directly from the copyright holder. To view a copy of this licence, visit http://creativecommons.org/licenses/by/4.0/.

\section{References}

Papers of particular interest, published recently, have been highlighted as: • Of importance

1. Bhatia KP, Bain P, Bajaj N, Elble RJ, Hallett M, Louis ED, et al. Consensus statement on the classification of tremors. from the task force on tremor of the International Parkinson and Movement Disorder Society. Mov Disord. 2018;33:75-87.

2. Tarakad A, Jankovic J. Essential tremor and parkinson's disease: exploring the relationship. Tremor and Other Hyperkinetic Movements. 2019;9:1-10.

3. Burne JA, Hayes MW, Fung VSC, Yiannikas C, Boljevac D. The contribution of tremor studies to diagnosis of Parkinsonian and essential tremor: a statistical evaluation. J Clin Neurosci. 2002;9:237-42. 
4. Helmich RC, Toni I, Deuschl G, Bloem BR. The pathophysiology of essential tremor and Parkinson's tremor. Curr Neurol Neurosci Rep. 2013;13:378 (Springer US).

5. Rajput AH, Adler CH, Shill HA, Rajput A. Essential tremor is not a neurodegenerative disease. Neurodegener Dis Manag Future Medicine Ltd. 2012;2:259-68.

6. Louis ED, Faust PL. Essential tremor: The most common form of cerebellar degeneration? Cerebellum and Ataxias. 2020;7:12. https://doi.org/10.1186/s40673-020-00121-1

7. Deuschl G, Raethjen J, Hellriegel H, Elble R. Treatment of patients with essential tremor. Lancet Neurol. Elsevier; 10:14861. https://doi.org/10.1016/S1474-4422(10)70322-7.

8. Colebatch JG, Frackowiak RSJ, Brooks DJ, Colebatch JG, Findley LJ, Marsden CM. Preliminary report: activation of the cerebellum in essential tremor. Lancet. 1990;336:1028-30.

9. Jenkins IH, Bain PG, Colebatch JG, Thompson PD, Findley LJ, Frackowiak RSJ, et al. A positron emission tomography study of essential tremor: Evidence for overactivity of cerebellar connections. Ann Neurol. 1993;34:82-90.

10. Wills AJ, Jenkins IH, Thompson PD, Findley LJ, Brooks DJ. Red nuclear and cerebellar but no olivary activation associated with essential tremor: a positron emission tomoraphic study. Ann Neurol. 1994;36:636-42.

11. Wills AJ, Jenkins LH, Thompson PD, Findley LJ, Brooks DJ. A positron emission tomography study of cerebral activation associated with essential and writing tremor. Arch Neurol Arch Neurol. 1995;52:299-305.

12. Czarnecki K, Jones DT, Burnett MS, Mullan B, Matsumoto JY. SPECT perfusion patterns distinguish psychogenic from essential tremor. Park Relat Disord Parkinsonism Relat Disord. 2011;17:328-32.

13. Hallett M, Dubinsky RM. Glucose metabolism in the brain of patients with essential tremor. J Neurol Sci J Neurol Sci. 1993;114:45-8.

14. Ha SW, Yang YS, Song IU, Chung YA, Oh JK, Chung SW. Changes in regional brain glucose metabolism measured with F-18-FDG-PET in essential tremor. Acta radiol. 2015;56:482-6.

15. Song I-U, Ha S-W, Yang Y-S, Chung Y-A. Differences in regional glucose metabolism of the brain measured with F-18FDG-PET in patients with essential tremor according to their response to beta-blockers. Korean J Radiol. 2015;16:967.

16. Verger A, Witjas T, Carron R, Eusebio A, Boutin E, Azulay JP, et al. Metabolicpositron emission tomography response to gamma knife of the ventral intermediate nucleus in essential tremor. Neurosurgery. 2019;84:E294-303. This study used FDG-PET to analyse brain metabolic characteristics in $\mathbf{4 2}$ ET patients before and after Vim thalamotomy. Dynamic changes in cerebral metabolism after surgery were found aftery surgery, indicating potential therapeutic biomarkers.

17. Barath AS, Rusheen AE, Min HK, Lee J, Ross E, Shin S, et al. Brain metabolic changes with longitudinal transcutaneous afferent patterned stimulation in essential tremor subjects. Tremor and Other Hyperkinetic Movements. Center for Digital Research and Scholarship; 2020;10:1-10. This study used FDG-PET to characterise metabolic brain changes before and 90 days after the application of a novel treatment for essential tremor, transcutanous afferent patterned stimulation. FDG-PET revealed increased metabolism in the cerebellar hemisphere ipsilateral to the stimulation and hypometabolism contralaterally, and a moderate-strong correlation was found between the change in tremor severity and the change in FDG uptake in the hypermetabolic hemicerebellum.

18. Lin PT, Ross EK, Chidester P, Rosenbluth KH, Hamner SR, Wong $\mathrm{SH}$, et al. Noninvasive neuromodulation in essential tremor demonstrates relief in a sham-controlled pilot trial. Mov Disord. 2018;33:1182-1183. https://doi.org/10.1002/mds.27350
19. Brooks DJ, Playford ED, Ibanez V, Sawle GV, Thompson PD, Findley $\mathrm{CW}$, et al. Isolated tremor and disruption of the nigrostriatal dopaminergic system: an 18F-dopa PET study. Neurology Wolters Kluwer Health, Inc on behalf of the American Academy of Neurology. 1992;42:1554-60.

20. Parkinson Study Group. A multicenter assessment of dopamine transporter imaging with DOPASCAN/SPECT in parkinsonism. Neurology. 2000;55:1540-7.

21. Benamer TS, Patterson J, Grosset DG, Booij J, de Bruin K, van Royen E, et al. Accurate differentiation of parkinsonism and essential tremor using visual assessment of [123I]-FP-CIT SPECT imaging: the [123I]-FP-CIT study group. Mov Disord. 2000;15:503-10.

22. Antonini A, Moresco RM, Gobbo C, De Notaris R, Panzacchi $\mathrm{A}$, Barone $\mathrm{P}$, et al. The status of dopamine nerve terminals in Parkinson's disease and essential tremor: a PET study with the tracer [11-C]FE-CIT. Neurol Sci. 2001;22:47-48. https://doi. org/10.1007/s100720170040.

23. Di Giuda D, Camardese G, Bentivoglio AR, Cocciolillo F, Guidubaldi A, Pucci L, et al. Dopaminergic dysfunction and psychiatric symptoms in movement disorders: a 123I-FP-CIT SPECT study. Eur J Nucl Med Mol Imaging. 2012;39:1937-48.

24. Isaias IU, Marotta G, Hirano S, Canesi M, Benti R, Righini A, et al. Imaging essential tremor. Mov Disord. 2010;25:679-86.

25. Roselli F, Pisciotta NM, Pennelli M, Aniello MS, Gigante A, De Caro MF, et al. Midbrain SERT in degenerative parkinsonisms: a 123I-FP-CIT SPECT study. Mov Disord Mov Disord. 2010;25:1853-9.

26. Asenbaum S, Pirker W, Angelberger P, Bencsits G, Pruckmayer M, Brücke T. [123I] $\beta$-CIT and SPECT in essential tremor and Parkinson's disease. J Neural Transm. 1998;105:1213-28.

27. Lee MS, Kim YD, Im JH, Kim HJ, Rinne JO, Bhatia KP. 123IIPT brain SPECT study in essential tremor and Parkinson's disease. Neurology. 1999;52:1422-6.

28. Schwartz M, Groshar D, Inzelberg R, Hocherman S. Dopaminetransporter imaging and visuo-motor testing in essential tremor, practical possibilities for detection of early stage Parkinson's disease. Park Relat Disord Elsevier. 2004;10:385-9.

29. Ceravolo R, Antonini A, Volterrani D, Rossi C, Kiferle L, Frosini D, et al. Predictive value of nigrostriatal dysfunction in isolated tremor: a clinical and SPECT study. Mov Disord. 2008;23:2049-54.

30. De Verdal M, Renard D, Collombier L, Boudousq V, Kotzki PO, Labauge P, et al. I123-FP-CIT single-photon emission tomography in patients with long-standing mixed tremor. Eur J Neurol. 2013;20:382-8.

31. Coria F, Gimenez-Garcia M, Samaranch L, Mora FJ, SampolBas C, Pastor P. Nigrostriatal dopaminergic function in subjects with isolated action tremor. Park Relat Disord Elsevier Ltd. 2012;18:49-53.

32. Waln O, Wu Y, Perlman R, Wendt J, Van AK, Jankovic J. Dopamine transporter imaging in essential tremor with and without parkinsonian features. J Neural Transm Springer Vienna. 2015;122:1515-21.

33. Novellino F, Arabia G, Bagnato A, Cascini GL, Salsone M, Nicoletti G, et al. Combined use of DAT-SPECT and cardiac MIBG scintigraphy in mixed tremors. Mov Disord. 2009;24:2242-8.

34. Louis ED, Faust PL, Vonsattel JPG, Honig LS, Rajput A, Robinson CA, et al. Neuropathological changes in essential tremor: 33 cases compared with 21 controls. Brain Oxford University Press. 2007;130:3297-307.

35. Boecker H, Weindl A, Brooks DJ, Ceballos-Baumann AO, Liedtke C, Miederer M, et al. GABAergic dysfunction in essential tremor: an 11c-flumazenil PET study. J Nucl Med J Nucl Med. 2010;51:1030-5. 
36. Gironell A, Figueiras FP, Pagonabarraga J, Herance JR, PascualSedano B, Trampal C, et al. Gaba and serotonin molecular neuroimaging in essential tremor: a clinical correlation study. Park Relat Disord Elsevier Ltd. 2012;18:876-80.

37. Louis ED, Hernandez N, Dyke JP, Ma RE, Dydak U. In vivo dentate nucleus gamma-aminobutyric acid concentration in essential tremor vs. controls. Cerebellum. 2018;17:165-72 (Springer New York LLC).

38. Roselli F, Pisciotta NM, Pennelli M, Aniello MS, Gigante A, De Caro MF, et al. Midbrain SERT in degenerative parkinsonisms: A 123I-FP-CIT SPECT study. Mov Disord. 2010;25:1853-9.

39. Goetz CG, Tilley BC, Shaftman SR, Stebbins GT, Fahn S, Martinez-Martin P, Poewe W, Sampaio C, Stern MB, Dodel R, Dubois B, Holloway R, Jankovic J, Kulisevsky J, Lang AE, Lees A, Leurgans S, LeWitt PA, Nyenhuis D, Olanow CW, Rascol O, Schrag A, Teresi JA, van Hilten JJ, LaPelle N. Movement Disorder Society-sponsored revision of the Unified Parkinson's Disease Rating Scale (MDS-UPDRS): Scale presentation and clinimetric testing results. Mov Disord. 2008;23:2129-2170. https://doi.org/10.1002/mds.22340.

40. Helmich RC, Hallett M, Deuschl G, Toni I, Bloem BR. Cerebral causes and consequences of parkinsonian resting tremor: a tale of two circuits? Brain. 2012;135:3206-26.

41. Dirkx MF, Zach H, Bloem BR, Hallett M, Helmich RC. The nature of postural tremor in Parkinson disease. Neurology. 2018;90:e1095-103.

42. Belvisi D, Conte A, Cutrona C, Costanzo M, Ferrazzano G, Fabbrini G, et al. Re-emergent tremor in Parkinson's disease: the effect of dopaminergic treatment. Eur J Neurol. 2018;25:799-804.

43. Parker F, Tzourio N, Blond S, Petit H, Mazoyer B. Evidence for a common network of brain structures involved in Parkinsonian tremor and voluntary repetitive movement. Brain Res Elsevier. 1992;584:11-7.

44. Deiber MP, Pollak P, Passingham R, Landais P, Gervason C, Cinotti $\mathrm{L}$, et al. Thalamic stimulation and suppression of parkinsonian tremor: evidence of a cerebellar deactivation using positron emission tomography. Brain Brain. 1993;116:267-79.

45. Davis KD, Taub E, Houle S, Lang AE, Dostrovsky JO, Tasker RR, Lozano AM. Globus pallidus stimulation activates the cortical motor system during alleviation of parkinsonian symptoms. Nat Med. 1997;3(6):671-4. https://doi.org/10.1038/ nm0697-671.

46. Eidelberg D, Moeller JR, Dhawan V, Spetsieris P, Takikawa S, Ishikawa T, et al. The metabolic topography of Parkinsonism. J Cereb Blood Flow Metab. 1994;14:783-801 (Nature Publishing Group).

47. Ma Y, Tang C, Spetsieris PG, Dhawan V, Eidelberg D. Abnormal metabolic network activity in Parkinson's disease: test-retest reproducibility. J Cereb Blood Flow Metab. 2007;27:597-605 (NIH Public Access)

48. Eckert T, Tang C, Eidelberg D. Assessment of the progression of Parkinson's disease: a metabolic network approach. Lancet Neurol. 2007;6(10):926-32. https://doi.org/10.1016/ S1474-4422(07)70245-4.

49. Antonini A, Moeller JR, Nakamura T, Spetsieris P, Dhawan $\mathrm{V}$, Eidelberg D. The metabolic anatomy of tremor in Parkinson's disease. Neurology Lippincott Williams and Wilkins. 1998;51:803-10.

50. Mure H, Hirano S, Tang CC, Isaias IU, Antonini A, Ma Y, et al. Parkinson's disease tremor-related metabolic network: characterization, progression, and treatment effects. Neuroimage Neuroimage. 2011;54:1244-53.

51. Eggers C, Schwartz F, Pedrosa DJ, Kracht L, Timmermann L. Parkinson's disease subtypes show a specific link between dopaminergic and glucose metabolism in the striatum. PLoS ONE. 2014;9:1-7.

52. Eidelberg D, Moeller JR, Dhawan V, Sidtis JJ, Ginos JZ, Strother $\mathrm{SC}$, et al. The metabolic anatomy of Parkinson's disease: complementary $[18 \mathrm{~F}]$ fluorodeoxyglucose and $[18 \mathrm{~F}]$ fluorodopa positron emission tomographic studies. Mov Disord. 1990;5:203-13 (John Wiley \& Sons, Ltd).

53. Seibyl JP, Marchek KL, Quinlan D, Sheff K, Zoghbi S, ZeaPonce Y, et al. Decreased single-photon emission computed tomographic $\{123 \mathrm{I}\}$ ?-CIT striatal uptake correlates with symptom severity in Parkinson's disease. Ann Neurol. 1995;38:589-98.

54. Antonini A, Vontobel P, Psylla M, Günther I, Maguire PR, Missimer J, et al. Complementary positron emission tomographic studies of the striatal dopaminergic system in Parkinson's disease. Arch Neurol Arch Neurol. 1995;52:1183-90.

55. Vingerhoets FJG, Schulzer M, Calne DB, Snow BJ. Which clinical sign of Parkinson's disease best reflects the nigrostriatal lesion? Ann Neurol. 1997;41:58-64.

56. Otsuka M, Ichiya Y, Kuwabara Y, Hosokawa S, Sasaki M, Yoshida T, et al. Differences in the reduced18F-Dopa uptakes of the caudate and the putamen in Parkinson's disease: correlations with the three main symptoms. J Neurol Sci Elsevier. 1996;136:169-73.

57 Brücke T, Asenbaum S, Pirker W, Djamshidian S, Wenger S, Wöber $\mathrm{C}$, et al. Measurement of the dopaminergic degeneration in Parkinson's disease with [123I] beta-CIT and SPECT. Correlation with clinical findings and comparison with multiple system atrophy and progressive supranuclear palsy. J Neural Transm Suppl. 1997;50:9-24.

58. Rinne JO, Ruottinen H, Bergman J, Haaparanta M, Sonninen $\mathrm{P}$, Solin O. Usefulness of a dopamine transporter PET ligand $[18 F] \beta-C F T$ in assessing disability in Parkinson's disease. J Neurol Neurosurg Psychiatry. 1999;67:737-41 (BMJ Publishing Group).

59. Benamer HT, Patterson J, Wyper DJ, Hadley DM, Macphee GJ, Grosset DG. Correlation of Parkinson's disease severity and duration with 123I-FP-CIT SPECT striatal uptake. Mov Disord. 2000;15:692-8.

60. Haapaniemi TH, Ahonen A, Torniainen P, Sotaniemi KA, Myllyla VV. [123I]beta-CIT SPECT demonstrates decreased brain dopamine and serotonin transporter levels in untreated parkinsonian patients. Mov Disord. 2001;16:124-30.

61. Pirker W. Correlation of dopamine transporter imaging with parkinsonian motor handicap: How close is it? Mov. Disord. Mov Disord; 2003.

62. Winogrodzka A, Wagenaar RC, Bergmans P, Vellinga A, Booij J, van Royen EA, et al. Rigidity decreases resting tremor intensity in Parkinson's disease: a [123I] $\beta$-CIT SPECT study in early, nonmedicated patients. Mov Disord. 2001;16:1033-40.

63. Fois AF, Chang FC, Barnett R, London K, Mahant N, Ha A, et al. Rest tremor correlates with reduced contralateral striatal dopamine transporter binding in Parkinson's disease. Park Relat Disord Elsevier Ltd. 2021;85:102-8.

64. Spiegel J, Hellwig D, Samnick S, Jost W, Möllers M-O, Fassbender K, et al. Striatal FP-CIT uptake differs in the subtypes of early Parkinson's disease. J neural Transm (Vienna, Austria). 2007;114:331-5.

65. Rossi C, Frosini D, Volterrani D, De Feo P, Unti E, Nicoletti V, et al. Differences in nigro-striatal impairment in clinical variants of early Parkinson's disease: Evidence from a FP-CIT SPECT study. Eur J Neurol. 2010;17:626-30.

66. Eggers C, Kahraman D, Fink GR, Schmidt M, Timmermann L. Akinetic-rigid and tremor-dominant Parkinson's disease patients show different patterns of FP-CIT single photon emission 
computed tomography. Mov Disord. 2011;26:416-23 (John Wiley \& Sons, Ltd).

67. Jellinger K. Post mortem studies in Parkinson's disease - is it possible to detect brain areas for specific symptoms. J Neural Transm Suppl. Springer Wien; 1999; 1-29.

68. Helmich RC, Janssen MJR, Oyen WJG, Bloem BR, Toni I. Pallidal dysfunction drives a cerebellothalamic circuit into Parkinson tremor. Ann Neurol. 2011;69:269-81.

69. Doder M, Rabiner EA, Turjanski N, Lees AJ, Brooks DJ. Tremor in Parkinson's disease and serotonergic dysfunction: an 11CWAY 100635 PET study. Neurology Lippincott Williams and Wilkins. 2003;60:601-5.

70. Qamhawi Z, Towey D, Shah B, Pagano G, Seibyl J, Marek K, et al. Clinical correlates of raphe serotonergic dysfunction in early Parkinson's disease. Brain. 2015;138:2964-73.

71. - Pasquini J, Ceravolo R, Qamhawi Z, Lee JY, Deuschl G, Brooks DJ, et al. Progression oftremor in early stages of Parkinson's disease: a clinical and neuroimaging study. Brain. 2018;141:811-21. This study characterises the relationship between the relative contributions of the dopaminergic and serotonergic systems in the clinical manifestation of PD rest tremor and its response to levodopa.

72. Loane C, Wu K, Bain P, David J, Piccini P, Politis M. Serotonergic loss in motor circuitries correlates with severity of actionpostural tremor in PD. Neurology. 2013;80:1850-5.

73. Dirkx MF, Zach H, van Nuland AJ, Bloem BR, Toni I, Helmich RC. Cognitive load amplifies Parkinson's tremor through excitatory network influences onto the thalamus. Brain Oxford University Press. 2020;143:1498-511.

74. Isaias IU, Marzegan A, Pezzoli G, Marotta G, Canesi M, Biella GEM, et al. A role for locus coeruleus in Parkinson tremor. Front Hum Neurosci. 2011;5:179.

75. Nahimi A, Sommerauer M, Kinnerup MB, Østergaard K, Wintherdahl M, Jacobsen J, et al. Noradrenergic deficits in Parkinson disease imaged with 11C-MeNER. J Nucl Med. 2018;59:659-64.

76. - Kinnerup MB, Sommerauer M, Damholdt MF, Schaldemose JL, Ismail R, Terkelsen AJ, et al. Preserved noradrenergic function in Parkinson's disease patients with rest tremor. Neurobiol Dis. 2021;152:105295 This study used a novel PET tracer for the noradrenergic transporter (NET) in PD, 11C-MeNER, to highlight that tremulous patients have preserved locus coeruelus NET while denervated median raphe. Severity of median raphe NET denervation is associated with tremor severity. Elsevier Inc.

77. Rivest J, Marsden CD. Trunk and head tremor as isolated manifestations of dystonia. Mov Disord Mov Disord. 1990;5:60-5.

78. Quinn NP, Schneider SA, Schwingenschuh P, Bhatia KP. Tremor-some controversial aspects. Mov Disord Mov Disord. 2011;26:18-23.

79. Louis ED. When do essential tremor patients develop head tremor? influences of age and duration and evidence of a biological clock. Neuroepidemiology Neuroepidemiology. 2013;41:110-5.

80. - Ferrazzano G, Frantellizzi V, De Bartolo MI, De Feo MS, Conte A, Fabbrini G, et al. Isolated head tremor: a DAT-SPECT and somatosensory temporal discrimination study. Park Relat Disord. Elsevier Ltd; 2020;81:56-9. This study highlights isolated head tremor characteristics that suggest that this entity is a form of dystonia with presevered nigrostriatal DaT availability.

81. Karimi M, Perlmutter JS. The role of dopamine and dopaminergic pathways in dystonia: insights from neuroimaging. Tremor and Other Hyperkinetic Movements. 2015;5:280.

82. Williams L, Butler JS, O’Riordan S, Skeehan S, Collins C, Hutchinson M. Response to "isolated head tremor: a DAT SPECT and somatosensory temporal discrimination study." Parkinsonism Relat Disord Elsevier BV. 2021;87:166-7.

83. Raina GB, Cersosimo MG, Folgar SS, Giugni JC, Calandra C, Paviolo JP, et al. Holmes tremor. Neurology. 2016;86:931-8.

84. Joutsa J, Shih LC, Fox MD. Mapping Holmes tremor circuit using the human brain connectome. Ann Neurol. 2019;86:81220 (John Wiley and Sons Inc.).

85. Nieuwhof F, de Bie RMA, Praamstra P, van den Munckhof P, Helmich RC. The cerebral tremor circuit in a patient with Holmes tremor. Ann Clin Transl Neurol. 2020;7:1453-8.

86. Gajos A, Bogucki A, Schinwelski M, Sołtan W, Rudzińska M, Budrewicz $\mathrm{S}$, et al. The clinical and neuroimaging studies in Holmes tremor. Acta Neurol Scand. 2010;122:360-6.

87. Gajos A, Budrewicz S, Koszewicz M, Bieńkiewicz M, Dąbrowski J, Kuśmierek J, et al. Is nigrostriatal dopaminergic deficit necessary for Holmes tremor to develop? The DaTSCAN and IBZM SPECT study. J Neural Transm. 2017;124:1389-93.

88. Kinnerup MB, Sommerauer M, Damholdt MF, Schaldemose JL, Ismail R, Terkelsen AJ, et al. Preserved noradrenergic function in Parkinson's disease patients with rest tremor. Neurobiol Dis. 2021;152:105295 (Elsevier Inc.).

89. Lozza C, Marié R-M, Baron J-C. The metabolic substrates of bradykinesia and tremor in uncomplicated Parkinson's disease. Neuroimage Elsevier BV. 2002;17:688-99.

90. Caretti V, Stoffers D, Winogrodzka A, Isaias I-U, Costantino G, Pezzoli G, et al. Loss of thalamic serotonin transporters in early drug-naïve Parkinson's disease patients is associated with tremor: an [(123)I]beta-CIT SPECT study. J Neural Transm. 2008;115:721-9.

Publisher's Note Springer Nature remains neutral with regard to jurisdictional claims in published maps and institutional affiliations. 